\title{
PENGALIHAN HAK TAGIH SECARA CESSIE DALAM PEMBIAYAAN PROYEK KONSTRUKSI PEMERINTAH
}

\author{
Adri Dyasita \\ Fakultas Hukum Universitas Muhamadiyah Yogyakarta \\ andridyasita@gmail.com \\ Yohanes Sogar Simamora \\ Fakultas Hukum Universitas Airlangga \\ simamora_sogar@yahoo.com
}

\begin{abstract}
There are deviations in the project financing of cessie scheme in the construction services business in legal theory, (1) where the receivables are billed at the time the agreement does not exist, (2) there is a notification requirement (betekening), (3) risk factors in the construction work, and the last (4) on the problem of execution in the event of a payment failure. The approach method is the legislative approach and the conceptual approach. In providing financing, this project relies on the capabilities of bank analysis. And the contract of government construction employment can be guaranteed because it has a high value of certainty, even though there is an institution that protects it (fiduciary) but will have difficulties in its execution, it is necessary to have additional guarantees on the credit agreement
\end{abstract}

Keywords: Cessie; Employment Contracts; Financing.

\begin{abstract}
Abstrak
Ada beberapa penyimpangan dalam skema cessie pada pembiayaan proyek di bidang usaha jasa kontruksi dalam teori hukum, yaitu (1) dimana piutang yang ditagihkan pada saat perjanjian tidak ada, (2) adanya syarat pemberitahuan (betekening), dimana hal ini tidak diperlukan, (3) faktor resiko dalam perkerjaan konstruksi, dan terakhir (4) pada masalah eksekusi jika terjadi kegagalan pembayaran. Adapun pendekatan dalam penelitian ini adalah pendekatan perundang undangan dan pendekatan konseptual. Dalam pemberian pembiayaan proyek ini mengandalkan pada kemampuan dari analisa bank. Kontrak perkerjan konstruksi pemerintah dapat dijadikan jaminan karena memiliki nilai kepastian yang tinggi, walaupun ada lembaga lembaga yang melindunginya (fidusia) akan tetapi akan kesulitan dalam eksekusinya maka diperlukan adanya jaminan tambahan pada perjanjian kredit.
\end{abstract}

Kata Kunci: Cessie; Kontrak Kerja; Pembiayaan.

\section{PENDAHULUAN}

Di era Presiden Republik Indonesia (Joko Widodo), sektor infrastruktur menjadi salah satu prioritas program pemerintahannya guna mendorong laju pertumbuhan ekonomi nasional, menurut data Kementrian Perencanaan Pembangunan Negara (BAPENAS), pememerintah dalam lima tahun mendatang (2015-2019) mencanangkan pembanguanan infrastruktur di berbagai bidang, jalan tol sepanjang 1.000 kilometer, jalan baru 2.650 kilometer dan masih banyak lagi, hal itu dimaksutkan selain untuk memeratakan pembangunan, juga untuk menurunkan biaya logistik dan ekonomi biaya tinggi dapat ditekan, sebab itu di butukan para pelaku penyedia jasa 
infrastruktur yang tangguh dan kuat baik secara tehnik dan permodalannya. Guna mendukung pegadaan proyek-proyek infrastruktur selama pemerintahannya, Presiden telah menerbitkan Peraturan Presiden (Perpres) No.16 Tahun 2018 Tentang Pengadaan Barang/Jasa Pemerintah, dimana perpres ini dinilai lebih baik dalam menampung perkembangan kebutuhan pemerintah mengenai pengaturan atas pengadaan barang dan jasa dengan lebih baik.

Dengan banyaknya projek infrastruktur, maka banyak para penyedia jasa kostruksi yang mempersiapkan diri, terutama dalam segi permodalan, salah satu jurus andalan jika penyedia memiliki kontrak perkerjaan konstruksi tetapi memiliki kesulitan dalam permodalan adalah menjaminkan kontrak tersebut kepada bank guna mendapakan kredit modal kerja. Contoh pembiayaan proyek adalah pembiayaan pembangunan jalan di wilayah Surabaya Madura dengan instansi pemerintah Badan Pengembang Wilayah Surabaya Madura (BPWSM) dimana dilakukan oleh PT. Swarna Bumi Eka Putra, yang menjaminkan kontrak kerjanya senilai 11.250.000.000,( sebelas milyar dua ratus lima puluh juta rupiah) dengan Bank Rakyat Indonesia cabang Kertajaya, Surabaya. Untuk mendapatkan pinjaman modal kerja sebesar dua milyar rupiah, pengajuan kredit ini menggunakan skema cessie dimana hak tagih PT. Swarna Bumi Putra dialihakan kepada Bank Rakyat Indonesia, berupa fasilitas pinjaman/kredit dalam jenis kredit modal kerja rekening koran dengan witdrawal Approval maksimum dua milyar rupiah, dengan jangka waktu selama projek berlangsung dan dapat diperpanjang kembali.

Adapun sangat menarik untuk dibahas mengenai pinjaman dalam pembiayan project dimana skema pembiayaan pinjaman tersebut menggunakan skema cessie, dalam pembangunan infrastruktur yang pendanan ini memiliki karakter yang cukup sesuai dengan kebutuhan pembangunan tersebut meliputi, besarnya pendanaan, jangka waktu perikatan, system pengembalian dana, dan keberadaan kontrak sebagai jaminan. Dengan adanya penyerahan piutang secara cessie maka pihak ketiga menjadi kreditur yang baru yang menggantikan kreditur yang lama yang diikuti pula dengan beralihnya seluruh hak dan kewajiban kreditur lama terhadap debitur kepada pihak ketiga selaku kreditur baru. Hal ini dikarenakan pengalihan piutang secara cessie tidak mengakibatkan berakhirnya perikatan yang telah ada yang dibuat antara kreditur dengan debitur. Hubungan hukum antara debitur dan kreditur berdasarkan perjanjian kredit yang telah ada sebelumnya tidak menjadi putus, sehingga tidak terjadi hubungan hukum yang baru yang menggantikan hubungan hukum yang lama. ${ }^{1}$

Dalam akad perjanjian kredit ini menggunakan skema cessie sesuai pada Pasal 613 KUH Perdata menyebutkan bahwa: "Penyerahan akan piutang-piutang atas nama dan kebendaan tidak bertubuh lainnya, dilakukan dengan jalan membuat sebuah akta otentik atau di bawah tangan, dengan mana hak-hak atas kebendaan itu dilimpahkan kepada orang lain. Penyerahan yang demikian bagi si berhutang tidak

1 Yuristia Eka Erwanda, Analisis Yuridis Pengalihan Piutang Secara Cessie dan Akibat Hukumnya Terhadap Jaminan Utang Debitur (Studi Kasus atas Putusan PN Pekanbaru No. 22/Pdt.G/2016/PN.Pbr), Premis Law Journal, Vol. 18 (2017), diunduh dari https://jurnal.usu.ac.id/index.php/premise/article/view/20505/8769

Adri Dyasita; Y. Sogar Sinamora, Pengalihan Hak Tagih Secara Cessie Dalam Pembiayaan Proyek Konstruksi Pemerintah 
ada akibatnya, melainkan setelah penyerahan itu diberitahukan kepadanya atau secara tertulis disetujui dan diakuinya. Penyerahan tiap-tiap piutang karena surat bawa dilakukan dengan penyerahan surat itu; penyerahan tiap-tiap piutang karena surat ditunjuk dilakukan dengan penyerahan surat disertai dengan endosemen".

Unsur-unsur yang dapat disimpulkan berdasarkan Pasal 613 KUHPerdata tersebut dalam suatu tindakan cessie, yakni pertama dibuatkan akta otentik atau akta di bawah tangan. Kedua, hak-hak yang melekat pada piutang atas nama dialihkan/berpindah kepada pihak penerima pengalihan, dan ketiga yaitu Cessie hanya berakibat hukum kepada debitur jika telah diberitahukan kepadanya atau secara tertulis disetujui dan diakuinya. ${ }^{2}$ Dimana pada perjanjian kredit kontrak konstruksi dengan skema cessie ini memiliki kelemahan atara lain, dimana piutang yang diserahkan/di pindahkan pada saat perjanjian adalah tidak ada, dalam artian hak tagih tersebut ada jika penyedia jasa konstuksi menyelesaikan perkerjaanya; adanya ke enggan pihak pengguna jasa/pemerintah pemilik projek menanggapi surat pemberitahuan (betekening) dari pemberi kredit (bank); faktor resiko dalam perkerjaan konstruksi, yang dapat berakibat pada pembayaran projek; permasalahan eksekusi jika terjadi kegagalan pembayaran.

Berdasarkan uraian dari latar belakang tersebut pemasalahan yang menarik untuk dibahas dalam penelitian ini adalah mengenai kekuatan kontrak kontruksi pemerintah sebagai jaminan kredit dengan skema cessie, dan perlindungan hukum bagi kreditor jika terjadi kegagalan bayar. Selanjutnya berdasarkan rumusan masalah di atas maka tujuan dari penelitian ini adalah pertama untuk menganalisis lebih lanjut mengenai pembiayaan project melalui pengalihan hak tagih kontrak pekerjaan konstruksi pemerintah dalam tataran hukum beserta pelaksanaannya. Kedua, untuk menganalisis lebih lanjut mengenai perlindungan hukum bagi kreditor bilamana terjadi kegagalan pembayaran.

\section{METODE PENELITIAN}

Penulisan ini menggunakan 2 (dua) metode pendekatan yaitu Pendekatan perundang-undangan (Statute approach) dilakukan dengan menelaah semua undangundang dan regulasi yang terkait dengan isu hukum yang sedang ditangani ${ }^{3}$, khususnya Undang - Undang No.2 Tahun 2017 tentang Jasa Konstruksi, Undang Undang Nomor 7 tahun 1992 tentang Perbankan, dan KUHPerdata, dan Pendekatan konseptual (Conseptual Approach), beranjak dari pandangan-pandangaan dan doktrin-doktrin yang berkembang dalam ilmu hukum. Dengan mempelajari pandangan-pandangan dan doktrin-doktrin di dalam ilmu hukum, peneliti akan menemukan ide-ide yang melahirkan pengertian - pengertian hukum, konsep-konsep hukum, dan asas-asas hukum yang relevan dengan isu yang dihadapi. ${ }^{4}$

2 Subekti, Hukum Perjanjian, Jakarta: Intermasa, 1998, hlm. 71

3 Peter Mahmud Marzuki, Penulisan Hukum, Jakarta: Kencana Premada Media Group, 2014, hlm. 33

4 Ibid. hlm. 133

Adri Dyasita; Y. Sogar Sinamora, Pengalihan Hak Tagih Secara Cessie Dalam Pembiayaan Proyek Konstruksi Pemerintah 


\section{HASIL DAN PEMBAHASAN}

Kontrak konstruksi pada dasarnya merupakan perjanjian pemborongan bangunan di dalamnya berisi tentang perjanjian untuk melakukan perkerjaan sebagaimana diatur dalam Pasal 1601 KUHPerdata ialah, pihak yang satu (si pemborong) mengikatkan diri kepada pihak lain (si pemberi tugas) untuk menghasilkan suatu perkerjaan tertentu dengan harga tertentu, kemudian diatur lebih lanjut dalam Pasal 1604 - 1616 KUHPerdata, namun ketentuan dalam pasalpasal tersebut hanya sedikit memuat tentang hak-hak dan kewajiban para pihak. Akan tetapi berkaitan dengan Perpres no. 16 tahun 2018 tentang pengadaan barang dan jasa pemerintah telah menggunakan istilah pemborongan di rubah menjadi pekerjaan konstruksi

Untuk pengadaan jasa konstruksi instansi pemerintah, selain hukum perdata dan hukum pidana berlaku pula Hukum Administrasi Negara (HAN) dan Hukum Tata Usaha Negara (HTN) ini mengatur hubungan hukum antara negara (pejabat negara) dengan masyarakat, termasuk mengatur hubungan hukum antara pengguna jasa dengan penyedia jasa yang terjadi dalam proses persiapan pengadaan hingga penetapan, HAN juga menegaskan bahwa setiap keputusan pengguna jasa dalam proses tersebut merupakan keputusan pejabat negara, sehingga apabila tidak puas, maka penyedia jasa dapat menuntut dengan atau tanpa ganti rugi ke Pengadilan Tata Usaha Negata (PTUN) ${ }^{5}$ secara lebih spesifik landasan hukum terkait dengan perjanjian kontrak kerja pengadaan barang jasa konstruksi adalah sebagai berikut :

1. Undang-undang No. 2 Tahun 2017 tentang Jasa Konstruksi

2. Undang-Undang No. 5 Tahun 1999 Tentang Monopoli Persaingan Usaha Tidak Sehat

3. Undang-Undang No. 17 Tahun 2003 Tentang Keuangan Negara

4. Undang Undang No. 1 Tahun 2004 Tentang Perbendeharan Negara

5. Peraturan Presiden No. 16 Tahun 2018 Tentang Pengadaan Barang Dan Jasa Pemerintah.

Dari hukum dan peraturan diatas dapat dikatakan, bahwa dalam kontrak kontruksi menyangkut 3 hal antara lain yaitu pertama, mengandung dua unsur kepentingan, yaitu kesepakatan para pihak dan keselamatan umum, kedua kepentingan dari kedua belah pihak dimana terdapat manfaat bagi para pihak yang melakukan kesepakatan serta menyangkut masalah perdata, ketiga kepentingan publik, terutama menjaga keselamatan publik dan menyangkut masalah pelanggaran hak publik menyangkut masalah pidana. Selain itu, hakikat dari kontrak konstruksi itu sendiri menyangkut beberapa hal, antara lain ruang lingkup perkerjaan, harga, pelaksanaan dan kemungkinan persengketaan ${ }^{6}$.

\section{Proses Kontrak Konstruksi Pemerintah}

5 Sulistijo Sidarto, Proyek Infrastruktur \& Sengketa Konstruksi, Depok: Prenada Media group, 2018, hlm. 23

6 Ibid, hlm. 25

Adri Dyasita; Y. Sogar Sinamora, Pengalihan Hak Tagih Secara Cessie Dalam Pembiayaan Proyek Konstruksi Pemerintah 
Dalam proses kontrak konstruksi bangunan terdapat kegiatan atau fase yang harus dilalui sebelum terjadi kontrak tersebut:

1. Tahapan pemberitahuan/pengumunan dimana ini dilakukan secara umum atau terbatas akan dilaksanakan pekerjaan projek. (Pasal 38 Perpres No. 2 Tahun 2018)

2. Persyaratan prakualifikasi, klasifikasi dan klasifikasi perserta lelang. ditujukan untuk dapat penilaan terhadap para perserta lelang mengenai syarat, kemampuan ataupun mutu dari hasil perkejaan konstruksi yang dihasilkan. (Pasal 31 UU No.2 Tahun 2017)

3. Pemenuhan jaminan, yaitu jaminan yang tercantum pada Pasal 30 Perpres No.16 Tahun 2018 di wajibkan dalam kontrak konstruksi:

a) jaminan tender untuk mengajukan penawaran dalam tender.

b) jaminan sanggah banding, diperlukan jika ada permasalahan pada tahapan penawaran, hal ini diperlukan agar pihak yang merasa dirugikan pada tahapan ini bertanggung jawab bila bawasannya permasalahan dapat di selesaikan

c) jaminan pelaksana, bentuk penanggungan yang diberikan bank untuk menanggung pelaksanaan perkerjaan yang harus dilaksanankan oleh penyedia jasa pemenang tender.

d) jaminan uang muka. Yaitu jaminan dari bank yang harus di berikan penyedia jasa sebelum pembayaran uang muka dari pengguna jasa.

e) jaminan pemeliharaan, yaitu pada kontrak pekerjaan kontruksi ada masa pemeliharaan dimana dalam hal ini penyedia meninggalkan sisa tagihan sebagai uang retensi pada saat serah terima.

Pemenuhan jaminan ini sesuai dengan tahapan yang dilalui oleh perserta tender dan akan kembali jika masa jaminan telah usai, ada lagi yang berbeda pada kententuan jaminan pada Pasal 30 ayat 4 Perpres No.16 Tahun 2018, dimana bentuk jaminan ini: tidak bersyarat, mudah di cairkan dan paling lambat 14 hari kerja cair setelah surat rekomendasi/ perintah pencairan dari pokja pemilihan/PPK/pihak yang di berikuasa pokja/PPK diterima. Hal ini menandakan jika terindikasi ada wanprestasi dari peserta tender/penyedia jasa konstruksi maka secara sepihak dan tanpa bisa diganggu gugat pokja/PPK dapat mengambil uang jaminantanpa pesetujuan/izin dari pemilik jaminan terlebih dahulu. Tender merupakan pelelangan perkerjaan yang dilakukan secara terbuka dengan evaluasi penawaran penyedia jasa dilakukan dengan penilaian teknis dan harga, dimana metode evaluasi harga terendah digunakan dasar penetapan pemenang diantara penawaran yang memenuhi persyaratan teknis, sesuai Pasal 39 ayat 4 Perpes No.16 Tahun 2018.

\section{Kontrak Memiliki Nilai Kepastian Tinggi}

Dari uraian tersebut diatas maka kontrak konstruksi tersebut memiliki nilai kepastian yang tinggi, sebab dilihat dari proses pembentukannya dari tahapan prakualifikasi, tahapan klasifikasi, pemenuhan atas dana jaminan sampai tahapan penunjukan pemenang lelang menunjukan ke bonafitan pada penyedia jasa konstruksi yang memenangkan tender tersebut, hal ini juga dijabarkan melalui

Adri Dyasita; Y. Sogar Sinamora, Pengalihan Hak Tagih Secara Cessie Dalam Pembiayaan Proyek Konstruksi Pemerintah 
peraturan: Pasal 3 UU No.1 Tahun 2004 yang menyatakan bahwa setiap pejabat dilarang melakukan tindakan yang berakibat pengeluaran atas bebab APBN/APBD jika anggaran untuk pengeluaran tersebut tidak tersedia atau tidak cukup tersedia, dan pda ayat 7 menyatakan bahwa keterlambatan pembayaran atas tagihan yang berkaitan dengan pelaksanaaan APBN/APBD dapat mengakibatkan pengenaan denda dan bunga; Pasal 52 Ayat 2 Perpres No.16 Tahun 2018 menyebutkan PPK dilarang mengadakan ikatan perjanjian atau menendatangani kontrak dengan penyedia, dalam hal belum tersedia anggaran belanja atau tidak cukup tersedia anggaran belanja yang dapat mengakibatkan dilampoinya batas anggaran belanja yang tersedia untuk kegiatan yang di biayai APBN/APBD.

Dengan demikian dapat ditarik kesimpulan dengan adanya kontrak konstruksi telah memiliki ketersedian dana yang telah ditetapkan oleh pengguna jasa (pemerintah) sehingga dalam hal ini pihak ke tiga (bank) pemberi kerdit mempunyai gambaran yang pasti tentang pengembalian dana pinjaman sesuai prinsip dan aturan dalam perbankan. ${ }^{7}$ Penjaminan kontrak perkerjaan konstruksi guna pemberian kridit diperbolehkan dan di fasilitasi oleh pemerintah dengan dasar Kepres No.29 Tahun 1984 pada Pasal 26 yang berbunyi:

1) Pemborong/rekanan yang memperoleh pekerjaan pemborongan/pembelian dari Pemerintah dapat memperoleh kredit dari bank milik pemerintah untuk membiayai pelaksanaan pekerjaan tersebut;

2) Pembayaran sebagaimana ditetapkan dalam surat perjanjian/kontrak yang bersangkutan dilakukan melalui bank milik pemerintah pemberi kredit dan di pergunakan pertama-tama untuk melunasi kewajiban pembayaran kembali kredit;

3) Gubernur Bank Indonesia dengan memperhatikan pertimbangan Menteri Keuangan mengatur lebih lanjut pelaksanaan ketentuan ayat (1) dan ayat (2).

Hal ini sejalan dengan program pemerintah untuk menunjang pertumbuhan dan kelancaran pembangunan, serta memperkuat kemampuan perkerja kontruksi dalam memenuhi progres perkerjaanya.

\section{Kredit Kontruksi}

Dalam pemberian kredit kontrak perkerja konstruksi bank memiliki 2 prinsip yang harus dipenuhi yaitu mengenai jaminan dan lembaga jaminan atau ikatan kreditnya, kerana pada dasarnya bank dilarang memberikan kredit tanpa adanya jaminan, dapat kita temukan dalam Pasal 24 Undang Undang No.14 Tahun 1967 tentang Pokok-Pokok Perbankan yang berbunyi” Bank Umum tidak memberi kredit tanpa jaminan kepada siapa pun juga”. ${ }^{8}$ Disamping itu dalam bank juga berlaku asas

7 Wawancara dengan praktisi Bank Jatim Surabaya, 25 Juli 2018.

8 Dalam penjelasan UU No.14 Tahun 1967, yang dimaksud dengan jaminan dalam ayat ini adalah jaminan dalam arti luas, yaitu jaminan yang bersifat materiil maupun yang bersifat immaterial. Dalam hubungan ini perlu kiranya dikemukakan, bahwa bank-bank dalam menilai suatu permintaan kredit biasanya berpedoman kepada faktor-faktor antara lain watak, kemampuan, modal, jaminan dan kondisikondisi ekonomi.

Adri Dyasita; Y. Sogar Sinamora, Pengalihan Hak Tagih Secara Cessie Dalam Pembiayaan Proyek Konstruksi Pemerintah 
commandi terings verbod, yaitu larangan bagi bank, bahwa pemberian kridit tersebut bank menjamin resiko kerugian si debitur, dalam artian jika debitur tidak dapat memenuhi hutangnya, maka tersedia jaminan tambahan, dimana hal tersebut dapat berupa barang bergerarak/tidak bergerak, jaminan perorangan (penanggungan/brougtocht) surat berharga dan lain-lain, bank dapat mencairkan jaminan lain tersebut sebagai pemenuhan hutang si debitur dengan segera. Dengan adanya 2 prinsip bank tersebut dalam kredit perkerjaan kontruksi terdapat 2 jenis jaminan dalam pelaksanannya yaitu:

a) Jaminan pokok, yaitu jaminan yang terkait dengan fasilitas kridit yang diajuakan atau jaminan yang berasal dari project yang dibiayai (berupa hak tagih dari prestasi atas kontrak pekerjaan konstruksi tersebut).

b) Jaminan tambahan, yaitu jaminan yang tidak terkait fasilitas kredit yang di ajukan, berupa fixed asset (harta tetap) milik debitur

c) Jaminan pelengkap, yaitu jaminan diluar harta tetap seperti jaminan perorangan (Personal Guarantee, borgtoch atau avalist) atau jaminan perusahaan (corporate guarante)

Dalam pemberia kredit kontrak pekerjaan konstruksi, bang selaku lembaga keungan harus menerapkan prinsip kehati-hatian, analisa kredit sesuai pedoman dan peraturan yang berlaku, adapun penerapan prinsip 5C, 5P dan 3R yaitu: ${ }^{9}$ Prinsip 5C:

1) Character (watak/kepribadian). Hal ini dimaksudkan untuk mengetahui kejujuran dan iktikad baik calon debitur untuk melunasi atau mengembalikan pinjamannya, sehingga tidak akan menyulitkan bank di kemudian hari.

2) Capacity (kemampuan). Bank harus meneliti tentang keahlian calon debitur dalam bidang usahanya dan kemampuan manajerialnya, sehingga bank yakin bahwa usaha yang akan dibiayainya dikelola oleh orang-orang yang tepat, sehingga calon debiturnya dalam jangka waktu tertentu mampu melunasi atau mengembalikan pinjamannya.

3) Capital (modal). Bank harus melakukan analisis terhadap posisi keuangan secara menyeluruh mengenai masa lalu dan yang akan datang, sehingga dapat diketahui kemampuan permodalan calon debitur dalam menunjang pembiayaan proyek atau usaha calon debiutr yang bersangkutan.

4) Collateral (agunan). Bank wajib meminta agunan tambahan dengan maksud jika calon debitur tidak dapat meluansi kreditnya, maka agunan tambahan tersebut dapat dicairkan guna menutupi pelunasan atau pengembangan kredit atau pembiayaan yang tersisa.

5) Condition of economy (prospek usaha nasabah debitur). Bank harus menganalisis keadaan pasar di dalam dan di luar negeri, baik masa lalu maupun yang akan datang, sehingga masa depan pemasaran dari hasil proyek atau usaha calon debitur yang dibiayai dapat pula diketahui.

Prinsip 5P meliputi atas: hlm. 162

9Maryanto Supriyono, buku pintar perbankan, Yokyakarta: CV Andi 2011,

Adri Dyasita; Y. Sogar Sinamora, Pengalihan Hak Tagih Secara Cessie Dalam Pembiayaan Proyek Konstruksi Pemerintah 
1) Personality (kepribadian). Dalam hal ini bank perlu mengumpulkan data-data mengenai calon debitur.

2) Purpose (tujuan). Bank wajib menyoroti tujuan penggunaan dari kredit tersebut.

3) Payment (pembayaran). Bank wajib memperhatikan kelancaran aliran dana (cash flow).

4) Prospect (masa depan). Bank wajib memperhatikan masa depan kegiatan yang mendapatkan pembiayaan kredit tersebut.

5) Protection (perlindungan). Diperlukan suatu perlindungan terhadap kredit oleh perusahaan debitur.

Sementara penilaian terhadap Prinsip $3 R$ meliputi atas :

a) Return (balikan). Maksudnya hasil yang akan dicapai dari kegiatan yang mendapatkan pembiayaan tersebut.

b) Repayment (pembayaran kembali).

c) Risk Bearing Ability (kemampuan menanggung risiko).

\section{Cessie Dalam Kredit Konstruksi}

Cessie adalah pemindahan hak piutang, yang sebetulnya merupakan penggantian orang berpiutang lama, yang dalam hal ini dinamakan cedent, dengan seseorang berpiutang baru, yang dalam hubungan ini dinamakan cessionaris. 10 Cessie merupakan bentuk skema perpindahan hukum hak tagih (piutang) dalam kontrak perkerjaan konstruksi diartikan sebagai piutang yang akan di cessiekan dari penyedia jasa konstruksi (cedent) kepada debitor baru yaitu bank (cessieonaris), hak tagih ini termasuk termasuk barang yang akan ada milik debitur pasal 1131 BW. Bawasannya hak tagih tersebut timbul jika debitur telah memenuhi kewajibannya atau menyelesaikan perkerjaannya. Dalam artian bahwa piutang tersebut pada pristiwa perjanjian kredit tersebut belum ada, atau piutang tersebut ada setelah debitur/penyedia jasa konstruksi/cedent tersebut telah menyelesaikan prestasi/kerja sesuai yang di perjanjiakan kepada pengguna jasa/cessus.

\section{Penyimpanga Dari Pengalihan Hak Tagih}

Dalam pembiayaan projek ini terjadi penyimpangan dimana pihak cedent menyerahkan hak piutang atas nama berupa kontrak perkerjaan kontrksi (berbentuk surat perintah kerja (SPK) atau surat perjanjian) yang ia punyai kepada cessionaris/bank untuk memperoleh pinjaman/kredit sebagai jaminan pembayaran atas hutang. Pengertian jaminan kebendaan pada penjaminan kontrak ini adalah hak tagih, dimana hak tagih ini termasuk benda tidak berwujut Pasal 503 BW yang berbunyi ada barang bertubuh dan ada barang tidak bertubuh, dan termasuk barang yang akan ada milik debitur Pasal 1131 BW. Bawasannya hak tagih tersebut timbul jika debitur telah memenuhi kewajibannya atau menyelesaikan perkerjaannya. Dalam artian bahwa piutang tersebut pada pristiwa perjanjian kredit tersebut belum ada,

10 Arfi David Kandou, Pengalihan Hak Tagih Kepada Pihak Ketiga melalui Cassie menurut Pasal 613 KUHPerdata Dalam Pemberian Kredit Bank, Lex Privatum Vol. VI/No. 5/Juli/2018, hlm. 101

Adri Dyasita; Y. Sogar Sinamora, Pengalihan Hak Tagih Secara Cessie Dalam Pembiayaan Proyek Konstruksi Pemerintah 
atau piutang tersebut ada setelah debitur/penyedia jasa konstruksi/cedent tersebut telah menyelesaikan prestasi/kerja sesuai yang di perjanjikan kepada pengguna jasa cessus. Kontrak mengandung suatu nilai kepastian pembayaran yang tinggi dimana terdapat banyak syarat dan ketentuan yang harus di lengkapi dan dipenuhi oleh penyedia jasa konstruksi pada tahapan awal tender, berserta jaminan yang harus dipenuhi oleh penyedia jasa konstruksi melalui lembaga keungan/bank yang telah dijabarkan pada sub bab diatas sebelum pembentukan kontrak konstruksi.

Selain itu ada batasan batasan bagi pejabat pemerintah dalam pengelolaan keungan negara, asas umum pengelolan terkait atas beban APBN, ${ }^{11}$ dapat kita jumpai dalam Pasal 3 UU No.1 Tahun 2004 yang menyatakan bahwa setiap pejabat dilarang melakukan tindakan yang berakibat pengeluaran atas bebab APBN/APBD jika anggaran untuk pengeluaran tersebut tidak tersedia atau tidak cukup tersedia, dan pada Pasal 3 ayat 7 menyatakan bahwa keterlambatan pembayaran atas tagihan yang berkaitan dengan pelaksanaaan APBN/APBD dapat mengakibatkan pengenaan denda dan bunga juga pada Pasal 52 ayat 2 Perpres No.16 tahun 2018 menyebutkan PPK dilarang mengadakan ikatan perjanjian atau menendatangani kontrak dengan penyedia, dalam hal belum tersedia anggaran belanja atau tidak cukup tersedia anggaran belanja yang dapat mengakibatkan dilampoinya batas anggaran belanja yang tersedia untuk kegiatan yang di biayai APBN/APBD.

Dari penjelasan tersebut dapat ditarik suatu kesimpulan adanya kontrak perkerjaan konstruksi telah memiliki ketersedian dana yang telah ditetapkan oleh pengguna jasa (pemerintah) sehingga dalam hal ini pihak ke tiga (bank) pemberi kerdit mempunyai gambaran yang pasti tentang pengenbalian dana pinjaman sesuai prinsip dan aturan dalam perbankan. Ketersedian dana dalam kontrak ini menjadi salah satu dasar utama bank dalan mengalisa suatu permohonan pinjaman oleh penyedia jasa konstruksi untuk mengambil keputusan pemberian pinjaman. ${ }^{12}$ Walaupun pada dasarnya penjaminan kontrak ini lemah karena tidak adanya lembaga penjamin akan tetapi kontrak perkerjaan kontruksi memiliki nilai kepastian yang tinggi.

\section{Penyimpangan Atas Pemberitahuan Cessie (betekening)}

Selain itu juga terjadi penyimpangan pada simpulan syarat ke tiga Pasal 613 KUHPerdata yang berbunyi "Cessie hanya berakibat hukum kepada debitur jika telah diberitahukan kepadanya atau secara tertulis disetujui dan diakuinya”. Dimana pada kenyataan dilapangan pada cessus/ pengguna jasa konteruksi/pemerintah tidak mengindahkan atau tidak merasa perlu untuk menerima surat penegasan dari cessionaris/bank/ kreditur baru dengan alasan tidak merasa berkepentingan dan tidak mau tersangkut paut jika mungkin ada permasalahan antara pihak penyedia jasa konstruksi dengan bank selaku pemberi kredit/pinjaman. Hal ini sangat wajar dan masuk akal sehingga bank selaku pemberi pinjaman akan sangat selektif dalam memberi kredit, dalam artian bank yang akan memberikan kredit perkerjaan

11 sogar sinamora, op.cit, hlm.67

12 wawancara dengan praktisi Bank Jatim Surabaya, 25 Juli 2018,

Adri Dyasita; Y. Sogar Sinamora, Pengalihan Hak Tagih Secara Cessie Dalam Pembiayaan Proyek Konstruksi Pemerintah 
konstruksi ini hanyalah bank pemerintah, selain itu bank pemberi pinjaman adalah bank yang akan membayar kontrak konstrukdi tersebut, semisal untuk perkerjaan projek dari pemkot Surabaya maka bank pembayar adalah Bank Jatim sehingga pengajuan pinjaman penyedia jasa konstruksi juga ke Bank Jatim, jika ke bank lain kemungkinan besar tidak diterima, atau untuk projek pemerintah pusat, bank pembayar adalah Bank Rakyat Indonesia (BRI) maka penyedia jasa konteruksi dapat mengajukan kredit kepada BRI.

Selain itu ada klausul keamanan dalam perjanjian kredit yang disepakati para pihak, yang menyebutkan

1) Syarat pencantuman nomor rekening Bank pada surat perintah krja (SPK) atau surat perjanjian kontruksi sebagai rekening penampung (escrow account) pembayaran.

2) Debitur telah menyerahkan surat perintah (standing instruktion) kepada Bank untuk sewaktu-waktu dapat memindah bukukan dana dari escrow acount untuk keperluan pembayaran pinjaman.

3) Surat kuasa dari debitur kepada Bank untuk memberikan kuasa untuk menerima pembayaran dari buyer dan bila perlu dimintakan persetujuan dari buyer

4) Bank pada keadaan tertentu dapat memindah rekening dana/ mendebet saldo dari escrow account yang berasal dari kontrak lain

5) Kesangupan debitur untuk diperiksa administrasi pembukuan oleh bank atau pihak ke tiga yang ditunjuk bank.

Dengan adanya klusula ini dalam perjanjian kredit, pihak bank akan aman karena hadir dalam perjanjian kontrak konstruksi, dan akan selalu dapat mengontrol arus kas dari debitor.

\section{Perlindungan Hukum Kreditor}

Pemberian suatu pinjaman/kerdit pasti memiliki resiko yang harus di kelola dan ditata dengan baik oleh bank, adapun resiko tersebut terjadi dalam banyak hal. Resiko tersebut berupa keadaan dimana keridit tidak dapat kembali tepat pada waktumya, keridit bemasalah atau Non Performing Loan (NPL) diperbankan dapat disebabkan oleh berbagai faktor, semisal kesengajaan dari pihak-pihak yang terlibat dalam proses kredit tersebut, kesalahan prosedur pemberian keridit atau disebabkan faktor lain seperti faktor makro ekonomi ataupun faktor keadan khahar.

Salah satu bentuk antisipasi permasalahan kredit ada pada akta perjanjian kredit dan cessie telah terdapat beberapa solusi klausula keamanan untuk meminilalkan resiko, yang telah dipasang dan disepakati dalam pasal - pasal perjanjian bersama antara debitur dan kreditur dalam akta perjanjian kredit, antara lain: adanya asuransi jiwa bagi pemilik yang jika terjadi kejadian kecelakaan atau kematian maka jumlah petanggungan akan menjadi milik bank sebagai pengganti pembayaran hutang. Jika diperlukan Asuransi kontruksi (seperti Bencana alam, Kebakaran, Ledakan, Pencurian termasuk pencurian dengan paksa, Kelalaian pekerja, Kurang cakapnya pekerja, Penggunaan bahan yang keliru) disyaratkan guna kepentingan bank. Asuransi bangunan rumah yang di jadikan jaminan tambahan

Adri Dyasita; Y. Sogar Sinamora, Pengalihan Hak Tagih Secara Cessie Dalam Pembiayaan Proyek Konstruksi Pemerintah 
dalam kredit. Bank/kreditur berhak menolak pencairan kridit jika menurut pertimbangan bank membahayakan kedudukan bank. Syarat pencamtuman nomor rekening bank kreditur pada surat perjanjian kontruksi sebagai rekening penampung (escrow account) pembayaran. Debitur telah menyerahkan surat perintah (standing instruktion) kepada bank untuk sewaktu-waktu dapat memindah bukukan dana dari escrow acount untuk keperluan pembayaran pinjaman. Surat kuasa dari debitur kepada bank untuk memberikan kuasa untuk menerima pembayaran dari buyer dan bila perlu dimintakan persetujuan dari buyer. Bank pada keadaan tertentu dapat memindah rekening dana/ mendebet saldo dari escrow account yang berasal dari kontrak lain. Kesangupan debitur untuk diperiksa administrasi pembukuan oleh bank atau pihak ke tiga yang ditunjuk bank. Dan debitur berkewajiban segera memberitahu bank tentang masalah dan upaya penyelesaian mengenai, sengketa dengan pemerintah, tuntutan atau kerusakan dalan perkerjaan, tuntutan hukum terhadap debitor. Jika ternyata kredit mengalami kegagalan pembayaran ada 3 alternatif yaitu:

1. Penyelesaian secara internal

Penyelesain internal dimaksukan penyelesaian yang dilakukan antara bank dengan debitur secara musyawarah untuk mencapai kesepakatan antara lain ${ }^{13}$ :

a) Rescheduling, yaitu bebgan memperpanjang jangka waktu kredit dengan memperkecil angsuran pokok menjadi lebih ringan (umumnya untuk kredit investasi)

b) Rekonditioning, yaitu dengan mengubah beberapa persyaratan yang dinilai memberatkan

c) restrukturing, yaitu perubahan syarat kredit berupa penambahan dana dan/atau konversi seluruh atau sebagian dari kredit menjadi penyertaan modal

2. Penyelesaian secara eksternal.

Beberapa upaya penanganan penyelesaian kredit bermasalah yang lebih bersifat pemakaian kelembagaan hukum, di antaranya :

a) Melalui Panitia Urusan Piutang Negara dan Badan Urusan Piutang Negara (PUPN dan BUPN).

b) Melalui badan peradilan umum.

c) Melalui arbitrase atau Badan Alternatif Penyelesaian Sengketa.

3. Eksekusi jaminan

Yaitu dengan melalui parate eksekusi atau mengeksekusi sendiri/langsung (melelang) agunan tanpa campur tangan pengadilan.

13 Andhyta Larasati; Hendro Saptono; Rinitami Njatrijani, Analisis Yuridis Terhadap Pemberian Kredit Modal Kerja Konstruksi Pada PT. Bank Negara Indonesia TBK. Sentra Kredit Kecil Surakarta, Diponegoro Law Jurnal. Volume 5, Nomor 3, Tahun 2016, hlm. $7, \quad$ diunduh https://ejournal3.undip.ac.id/index.php/dlr/article/view/12893/12496 


\section{PENUTUP}

Pada dasarnya penjaminan kontrak perkerjaan konstruksi pemerintah atas suatu perjanjian pinjaman/kredit adalah lemah adanya, dilihat dari sisi eksekusi jika ada permasalahan didalamnya, akan tetapi kontrak konstruksi tersebut memiliki nilai kepastian yang tinggi, sebab dilihat dari proses pembentukannya dan peraturan perundang undangan yang mengaturnya, Dalam pemberian kredit bank melalui sekema cessie ini, bank harus menekankan pada analisis kredit sesuai prinsip kehati-hatian dan peraturan perbankan, salah satu penerapannya adanya jaminan tambahan yang di syaratkan. Pemberian suatu pinjaman/kerdit memiliki resiko yang harus dikelola dan ditata dengan baik oleh bank, agar tidak bermasalah pada kemudian hari semisal kesengajaan dari pihak-pihak yang terlibat dalam proses kredit tersebut, kesalahan prosedur pemberian keridit atau disebabkan faktor lain seperti faktor makro ekonomi ataupun faktor keadan khahar. Ada bentuk solusi antisipasi untuk mengatasi resiko tersebut seperti penerapan klasula keamanan dalam akta perjanjian yang disepakati para pihak. Akan tetapi jika terjadi kegagalan pembayaran kredit ada beberapa solusi penyelesaian seperti penyelesaian secara internal (melalui rescheduling, rekonditioning, restrukturing), penyelesaian secara eksternal (Panitia Urusan Piutang Negara, pengadilan umum dan abitrase) dan bisa juga melalui eksekusi lansung jaminan tambahan. Dalam penjaminan kontrak kerja konstruksi dianggap lemah karena permasalahan dalam eksekusi hal ini terjadi karena tidak ada perlindungan dalam peraturan yang kusus, sehingga perlu adanya peraturan yang lebih mengatur hal tersebut. Peran para analis perkreditan bank yang profesional dan objectif sangat di butuhkan dalam menganalisa pengajuan pinjaman, agar sesuai prinsip kehati hatian bank, menginagt maraknya penyelewengan kridit perbankan, terutama praktek kolusi dan akal-akan dalam praktik.

\section{DAFTAR PUSTAKA}

Erwanda, Yuristia Eka, 2017. Analisis Yuridis Pengalihan Piutang Secara Cessie dan Akibat Hukumnya Terhadap Jaminan Utang Debitur (Studi Kasus atas Putusan PN Pekanbaru No. 22/Pdt.G/2016/PN.Pbr), Premise Law Jurnal. Vol. 18 (2017), diunduh dari https://jurnal.usu.ac.id/index.php/premise/article/view/20505/8769

Kandou, Arfi David., 2018, Pengalihan Hak Tagih Kepada Pihak Ketiga melalui Cassie menurut Pasal 613 KUHPerdata Dalam Pemberian Kredit Bank, Lex Privatum Vol. VI/No. 5/Juli/2018.

Keputusan President Nomor 29 tahun 1984 tentang pelaksanaan anggaran pendapatan dan belanja Negara

Keputusan Direktur BI Nomor. 31/150/KEP/DIR tentang Restrukturisasi Kredit. 
Larasati, Andhyta; Hendro Saptono; Rinitami Njatrijani, 2016. Analisis Yuridis Terhadap Pemberian Kredit Modal Kerja Konstruksi Pada PT. Bank Negara Indonesia TBK. Sentra Kredit Kecil Surakarta, Diponegoro Law Jurnal. Volume 5, Nomor 3, Tahun 2016, hlm. 7, diunduh dari https://ejournal3.undip.ac.id/index.php/dlr/article/view/12893/12496

Marzuki, Peter Mahmud, 2014. Penelitian Hukum, kencana Premada Media Group, Jakarta.

Mengenal pembiayaan proyek financing” https://matthewhanzel.com/2017/03/20/ayo-nge-bank-mengenalpembiayaan-proyek-project-financing/

Peraturan Presiden Nomor 16 Tahun 2018, Tentang Pengadaan Barang/Jasa Pemerintah

Peraturan Presiden Nomor 38 Tahun 2015 Tentang Kerjasama Pemerintah Dengan Badan Usaha Umum.

Permenkeu Nomor. 265/PMK.08/2015 Tentang Fasilitas Dalam Rangka Penyiapkan Dan Pelaksannan Trasaksi Proyek Kerjasama Pemerintah Dan Badan Usaha

Peraturan Bank Indonesia Nomor. 6/18/PBI/2004 Tentang Kualitas Aktiva Produktif Bagi Bank Perkreditan Rakyat Syariah.

Peraturan Bank Indonesia Nomor 7/2/PBI/2005 Tentang Penilaian Kualitas Aktiva Bank Umum, Diubah Oleh PBI No.8/2/PBI/2006.

Sekilas skema pembiayaan proyek" http://kumpulanstudiaspirasi.com/ekonomi/sekilas-skema-pembiayaan-proyek/

Sidarto, Sulistijo. 2018. Proyek Infrastruktur \& Sengketa Konstruksi, Prenada Media Group, Depok.

Simamora, Y. Sogar, 2017. Hukum Kontrak, Surabaya: Laksabang Presindo.

Supriyono, Maryono. 2011, Buku Pintar Perbankan, Yokyakarta, CV Andi.

Subekti, 1998. Hukum Perjanjian, Jakarta: Intermasa.

Subekti; R Tjitrosudibio, 2014, Kitab Undang-Undang Hukum Perdata (Burgerlijk Wetboek), Jakarta, Pradnya Paramita. 
Supremasi Hukum : Jurnal Penelitian Hukum

p-ISSN: 1693-766X ; e-ISSN: 2579-4663, Vol. 27, No. 2, Agustus 2018, 151- 163

Undang Undang Nomor 2 Tahun 2017 Tentang Jasa Kontruksi.

Undang Undang Nomor 10 Tahun 1998 Tentang Perubahan

Undang Undang Nomor 7 Tahun 1992 Tentang Perbankan.

Undang Undang Nomor 4 Tahun 1996, Tentang Hak Tanggungan Atas Tanah

Undang Undang Nomor 42 Tahun 1999, Tentang Jaminan Fidusia

Undang Undang Nomor 17 Tahun 2003 Tentang Keuangan Negara

Undang Undang Nomor 1 Tahun 2004 Tentang Perbendeharan Negara

Undang Undang Nomor 5 Tahun 1999 Tentang Monopoli Persaingan Usaha Tidak Sehat

Wawancara, 2018, praktisi Bank Jatim Surabaya, 25 Juli 2018. 